COLLOQUIA HUMANISTICA

\author{
Sofija Grandakovska \\ John Jay College of Criminal Justice, City University of New York \\ New York \\ https://orcid.org/0000-0002-0155-0229 \\ grandakovska@gmail.com,sgrandakovska@jjay.cuny.edu
}

\title{
Mnemotope of Zion and Theopolitical Chronotopes in Ottoman Macedonia
}

\begin{abstract}
The discussion in the text, through the intersection of the disciplines of literature and history, oral poetry and ethical sermons from the period of the Enlightenment process in Ottoman Macedonia, aims to affirm the comparative relation between two questions. The first one is: How does one reach Zion (understood as a mnemotope) in the absence of a political identity of the Sephardim of Monastir (Bitola) within the framework of the Ottoman millet system? The second question is: How is the theo-messianic desire for Zion (understood as a vertical history) possible and accomplishable in the linearity of history, in the context of existing political chronotopes, or so-called ChristianOrthodox nationalisms in Ottoman Macedonia? In this complex historical period, the image of Zion does not have a real political place, but it still remains to emanate significant meaning about the homeland as a spiritual space.
\end{abstract}

Keywords: image of Zion, Monastirlis, Ottoman Macedonia, ChristianOrthodox nationalisms, Enlightenment, mnemotope, semantic memory, chronotope.

This is an Open Access article distributed under the terms of the Creative Commons Attribution 3.0 PL License (creativecommons.org/licenses/by/3.0/pl/), which permits redistribution, commercial and non-commercial, provided that the article is properly cited. (C) The Author(s), 2020.

Publisher: Institute of Slavic Studies, Polish Academy of Sciences

Editor-in-chief: Jolanta Sujecka

Conception and academic editing of this issue: Aleksandra Twardowska, Katarzyna Taczyńska 


\section{The Mnemotope of Zion: Between the Oral Poetry of the Macedonian Sephardim and Orthodox-Christian Nationalisms in Ottoman Macedonia}

שירו לנו משיר ציוך.

["Sing us one of the songs of Zion"

Psalm 137: 3.]

II O you know why the Torah begins with a beit and not with an aleph? Because the beginning of all beginnings is that letter which you can't even see" (Katz, 2012, p. 129). ${ }^{1}$ This statement, at the secondary level, holds an invocation for awareness to a state of creative activity which sets in motion the emergence of forms that are not yet articulated in reality. Accordingly, the potential of "'the primordial light' which was created long before the light of the sun, bringing it into close relationship with man, who was still a spiritual being at the time of creation..." (Mueller, 2008, p. 29) collaborates with the narrative of the beginning, or, as noted above, "the beginning of all beginnings." The main theme in this highly imaginative composition reveals the existence of a subtle moment of the future tense, or the image at its be-coming motion. My interest here, at the discursive level, is related to the semiotization of the inner principle of illumination and its iconic reflection in literature and history. It is in this connection that an equivalence between the trace at the mnemonic level and the historical context of the image of Zion is provided:

Here the skill of memory develops itself, based on the division of identity and territory....To remember the connections once established with places outside the homeland .... Thus, the boundaries between the homeland and the foreign land are not set geographically, but in a spiritual space .... We are spiritually connected to the community, and this is enabled through scriptures, written culture.... (J. Asman, 2011, pp. 222-223) ${ }^{2}$

The teachings of Rabbi Carlebach (1925-1994) on Genesis are presented in the book The Torah Commentary of Rabbi Shlomo Carlebach: Genesis, part 1 (Jerusalem/New York: Urim Publications, 2012), ed. by Katz Shlomo Rabbi. The excerpt above represents the end of Carlebach's brief teaching entitled "Shhhhh..." (Katz, 2012, p. 129), and refers to the first and second letter of the Hebrew alphabet. On this issue, please see one of the oldest and most important texts, published in the 12th century: Sepher HaBahir [The Book of Illumination], ascribed to Rabbi Nehunia ben HaKana.

2 All the following translations of quoted fragments are by the author of this text - S.G. 
The exterritorial (spiritual) qualification of the mnemotope of Zion implicitly evokes its genealogical history through "that letter which you can't even see"-first as an internal, intuitive or spiritual presence, and then as a historical reality. It is in this context that I intend to locate my introductory discussion between the image of Zion as a mnemotopic constant of the Jewish community of Monastir (Bitola) ${ }^{3}$ in Ottoman Macedonia ${ }^{4}$ and the theopolitical circumstances associated with the creation of the Balkan nation-states. In this complex historical period, the image of Zion did not have real a political place, but it still remained to emanate significant meaning about the homeland as a spiritual space. Namely, the Sephardim in Macedonia would actively meet with the political idea of Zionism ${ }^{5}$ in the period after the Ottoman Empire ceased to exist:

The Jewish Community of Monastir was the initiator of those activities .... In the early 1930s, the Zionist educational youth organization Hashomer Hacair was founded in Bitola. It was a left-wing oriented organization, based on the teachings of the famous Zionist-socialist ideologist Ber Borochov. According to him, a Jewish-Arab state with a socialist social structure and a Marxist-oriented ideology should be established in Israel. (Sadikario, 2008, pp. 28-29) ${ }^{6}$

In Ottoman Macedonia, at the heart of the struggles between the Greek Church and the Bulgarian Exarchate for political domination of OrthodoxChristian nationalisms, where "the first political mobilization, and thus

\footnotetext{
3 Bitola was part of the Pasha Sanjak. The Rumelia Eylate, the only administrative unit on European soil that united all the newly conquered territories until 1541, was divided into several sanjaks. Macedonia was covered by the following seven large sanjaks: Pasha, Kyustendil, Ohrid, Thessaloniki, Skopje, Ioannina and Lerin. See: Ǵorgiev, 2008, pp. 131-134, 2013, p. 1877.

4 "At first, the Ottoman authorities did not use the name Macedonia in the administrative sense, but rather called the newly conquered Balkan countries: Rumelia. However, the name Macedonia in the 19th century marked a territory that extends south to the Aegean Sea, encompassing the flow of the Bistrica, Vardar, Struma and Mesta rivers. From there, it turns north along the western Rhodopes towards Mount Rila, from where it turns northwest to the Osogovo Mountains, then continues west, forming the northern boundary that runs along the crest of Skopska Crna Gora and the Šar Mountains, the optimum northwestern border. From there, it turns south on the Korab, Dešat and Jablanica mountains, encompassing Lake Ohrid, and continues in the direction of Mount Gramos. It then turns east towards the Bistrica River in the direction of the Gulf of Salonika. This is the geographical, ethnographic and linguistic map according to which the affiliation of other Balkan as well as European countries was determined" (Ǵorgiev, 2013, p. 1871).

5 At the beginning of the 20th century, in Yugoslavia, there existed several Zionist societies: Gideon (1905) and Zion in Belgrade, as well as the Judeja Academic Club (1904) and Ahdus (1909) in Zagreb.

${ }_{6}$ Here, in his autobiographical introductory text, Sadikario explains in detail the structure and activities of this Zionist organization in Bitola, whose full name is Ken de Hashomer Hacair (Nest of Young Guards).
} 
the identification of the population, was based on Orthodox Christianity" (Donev, 2013, p. 2101), the community of Monastirlis existed between the "desire for Zion" (Alkalaj, 1910, pp. 4-5) and the absence of any concrete action for its political mobilization in the shattered millet system. Feeling the comfort of their Sephardic tradition after the Spanish exile; existing in relative isolation from the larger Jewish centers; lacking dynamic contact with the actual flows of Western European trends of modernization; still relishing in a hidden yet poor life in the Jewish quarter, understood as a micro-state with partial freedom granted by the Ottomans, with secular barriers incorporated in the Muslim court (Benbasa \& Rodrig, 2011, pp. 108-109) - all these aspects, roughly speaking, represent the center of a very shortened account of the enclosed society of the Jewish community in Monastir. The core bastions of Sephardic folklore: rabbinic authority, active synagogue life, religious schools (la skolika), and the realm of home where Ladino is the main spoken language - constitute the general locus where the dynamics and structure of the sociocultural practices of this Jewish community are embedded. Their activities, referring to the social memory aspect, follow the line from below to above. This supports the concept of how Monastirlis remember and observe historical events. In contrast, political memory moves from above to below and relates to the role of memory in the formation of collective identities through political action. Thus, the political memory appears to be a produced memory, since it is based on selection and exclusion in the process of constituting identity. Political memory is therefore necessarily mediated (A. Asman, 2015, pp. 76-77).

In the absence of organized secularization, ${ }^{7}$ understood as a strong cohesive relation between the theological and political realms, a role that the nation-state fulfills in the West, for the Monastirlis the image of Zion, rooted in traditional messianism, plays the role of semantic memory of the past. This is the key spot where history appears to exist as vertical, as a mechanism of the collective knowledge of the community. While the concept of nationalisms develops a horizontal line in the creation of statenational projects, understood as (re)grouping and producing multiplying identities on an Orthodox-Christian basis within the millet system, the Sephardim of Monastir remained outside this unifying theopolitical matrix. For this community, on an internal plan, the image of Zion perceived as a figure of memory of ancient history represents a type of "contemplative method" by which its collective historical identity is strengthened. This mnemotope presents a utopian space or a "place without a place." Yet,

For more details, see: Cohen, 2003. 
it could also be perceived as a heterotopic (real) place, since it could be located within the shared experience of the community:

...in so far as the mirror does exist in reality, where it exerts a sort of counteraction on the position that I occupy. From the standpoint of the mirror I discover my absence from the place where I am since I see myself over there. Starting from this gaze that is, as it were, directed toward me, from the ground of this virtual space that is on the other side of the glass, I come back toward myself; I begin again to direct my eyes toward myself and to reconstitute myself there where I am. (Foucault, 1984, p. 4)

The community of Monastirlis is considered one of the most conservative in the Balkans. It maintained the impenetrable shield of its traditional life (as a resistance to modernization) the longest, through tenacious preservation and practice of "the will to enclose in one place all times" (Foucault, 1984, p. 7). Such a qualitative determination of the community of the Monastirlis suggests that the image of Zion, in relation to the synchronicity of modern flows, fragmentation and with that, construction of modern identities on an Orthodox-Christian basis in the millet system, could be seen as an act of comparison between times and places: at once - Zion is here (as a vertical history) and Zion is far away. In this context, we could extract a dual epistemological attribute of the image of Zion: mnemotopic and chronotopic. However, the historical imagination - manifested through the communicative memory of the poetical oral heritage of the Monastirlis in relation to the image of Zion as an act of memory interaction - is not entirely absent. I use the notion of imagination, since the Sephardim of Monastir, through oral poetry, maintained awareness of the common ancient past as a structural knowledge of their collective unity, i.e. identity. Specifically, "an alreadymade geography sets the stage, while the voluntary creation of history dictates the action and defines the direction of development of the story" (Sodža, 2007, p. 49).

The oral cultural heritage of the Monastirlis, which they brought to the Ottoman Balkans after the Spanish and Portuguese pogroms, is collected in the book Roots (Sadikario, 2008). It represents anassemblage of poetry, proverbs and lamentations typical of the Bitola dialect of Ladino. ${ }^{8}$

8 The development and formation of this dialect was also influenced by the Portuguese language, through the arrival of Portuguese Jews in Bitola, who, by the end of the 18th century, were already assimilated by the Spanish Jews in Bitola. Judeo-Spanish, the spoken language of the Sephardim of Bitola, as noted by Sadikario, actually represents a Castilian dialect; it is the language of Cervantes, taken as literary language. The features of the 14th- to 15th-century language have been conserved in Ladino, remaining outside the transformations of the Spanish language (Sadikario, 2008, p. 37). For the specifics of the Bitola dialect of Ladino in the 
The collector is Avram Sadikario, who learned these pieces directly from his aunt (Tia Mircada) and his mother:

Most of the poems were transmitted from Spain, when in 1492 all the Jews who did not want to convert to Christianity were persecuted. Some of the poems were created by the Jews of Salonika, some are influenced by the Greek melos, some of them are oriental, i.e. the Turkish influence is obvious. But most of them are typically Sephardic. (Sadikario, 2008, p. 8) ${ }^{9}$

In this collection, ${ }^{10}$ the mnemotope of Zion, appearing as the revived space of memory, where the meaning of history as vertical is invoked and sustained, could be explicitly detected in the poem Jerusalem:

\author{
Yerushalayim, \\ Yerushalayim-madremiya \\ Muchotutravates \\ Travates tu dezgrayada \\ Mucho tu travates \\ Mozotros mos engradesermos \\ Mozotros mos engradesermos. \\ (Sadikario, 2008, p. 111)
}

\author{
[Jerusalem, \\ Jerusalem, our mother \\ You have endured a lot \\ You walked away, unhappy \\ You went away a lot \\ We will grow up \\ We will grow up.]
}

The presence of the mnemotope of Zion in the oral creations of the Sephardim of Monastir points to the important role that the cultural memory maintains as a collective notion of knowledge. It also supports the mnemonic preservation of collective practices by way of generational experiences of this particular group. Hence, the presence of the image of Zion through the oral poetry of the Monastirlis acquires the status of a collective communicative act through memory interaction. The image

oral pieces, I would refer to the following key studies: Grandakovska, 2011; Kolonomos, 1978; Luria, 1930; Vidaković-Petrov, 2009, 2011.

9 Avram Sadikario (1919-2007), pediatrician by profession, poet by vocation. In addition to collecting Sephardic poetry, which he was able to perform musically as well, he also published several collections of poetry in Macedonian: Ни крик ни самнина [No scream no loneliness] (1974), Очи и корень [Eyes and roots] (1974), Запалено лето [Fired summer] (1975), Погледи и звона [Horizons and bells] (1975), Ханилеа [Hanilea] (1985), Замолкнати правдини [Fade away justice] (1987), Оносветски призиви [Worldwide calls] (1995) and Датуми на пеколот [Dates of hell] (1996). His poetic output absolutely deserves to be investigated from a theoretical literary viewpoint. Here, I would also like to point out that his poetic manuscripts are preserved in the Avram Sadikario collection in the Archives of the Macedonian Academy of Sciences and Arts.

10 The two poems that explicitly refer to Zion are: Jerusalem [Jerushalayim] and Get Up [Alventad]. In this paper, I refer only to the former one. 
of Zion presents a subject for mutual exchange in the collective: It is socially mediated within the activities of this community as an image of the past.

The mnemotope of Zion ${ }^{11}$ transcends time, and thus communicative memory. In this context, in the continuation of the poem Jerusalem, the image of Zion is fixed at two levels: as a mnemotope (past) and as a political aspiration (future):

\begin{tabular}{c|c} 
I tesalvaremos & [And we will release you \\
Tesalvaremos & We will set you free \\
Tesalvaremos & From the damned hand.] \\
Di mano gitana. & \\
(Sadikario, 2008, p. 111) &
\end{tabular}

It is obvious that the poetic repetitive structural aspect of these verses is not solely significant as an exercise that nourishes the mnemotechnical ability of the group. This formal poetic tool also brings understanding of the vulnerability of the Jewish community existing far from the motherlocus; it expresses the inability of the collective to release itself from such bitter desire. In these verses, there is a double promise: (we) will grow up and (we) will set you free. The notion of promise, in its core body, implies the act: to give one's word. "Giving one's word" presents indebtedness to what the collective is committed to: Zion as a mother, the source of life, the spiritual homeland. These verses, through the covenant we will grow $u p$, also imply the future tense: promise (regarding the image of Zion) to obtain a relatively autonomous content of cultural memory in the form of political identity:

It could be said that political identity aspires to unification, utilitarianism, harmonization and homogenization, while cultural memory is characterized by a tense relationship between archiving and a symbolic repository on the one hand, and actualization of historical content in terms of its present purposes on the other. (J. Asman, 2011, p. 14)

The collective pronoun "we" contains the state of intimatization, a collective desire for the home, presenting an active medium in further

\footnotetext{
11 According to Jan Assmann (J. Asman, 2011, p. 64), cultural memory maintains a distance from everyday memory; it has its fixed points, and its horizon remains unchanged with the change that takes place in the present time. Fixed points refer to fateful events of the past that have become figures of memory through various cultural forms, such as texts, rituals, monuments, etc. They represent islands of time (this is an expression of Aby Warburg) or "mnemonic energy".
} 
accomplishment of the common political identity. "History is an image of change" (Albvaš, 2015, p. 58). In reality, the image of Zion appears as a symbolic reconstruction of the past. It is an aggregate of mnemonic narration: "Memory is created by preserved parts of the past that are reactualized (in consciousness or narration), but the same content could be shared by the entire group" (Sládeček \& Vasiljević, 2015, p. 8).

In the absence of political mobilization of the Sephardim of Monastir in Ottoman Macedonia, the image of Zion represents reservation of knowledge for positive self-determination. I will bring down this understanding to the syntagm that is us, as a notion for accumulated collective knowledge. It is in this place and through this self-semiqualifying attribute that relevance to the image of Zion is expressed in the present tense. Here, the image of Zion remains from the past, it exists now and here due to the normative factor of remembering in cultural, historical, and civilization endurance. The image of Zion performs a humanistic function as well, and in that sense, through the mnemonic aspect, it is obligatory for all times. At this point, history itself maintains verticality as a covenant for the future tense, or: we will grow up.

The genesis of that vertical history, at the literary-historical level, could be located in a few explicit spots in the Book of Psalms. As an illustrative example of the pre-text of the image of Zion, I will refer to Psalm 137, a poetic text belonging to the post-exile period after the Babylonian captivity. The psalmist, through poetic reflection on the traumatic experience of the episode of Jewish history related to the destruction of the temple, is actually self-positioning as a witness. The psalmist invokes memories of the home. By analogy, and in a comparative context, we are able to recognize the same episode as a position of an integrative factor of memory and history through the expression of mnemonic activity in the oral poetry of the Monastirlis. Hence, Zion is not just a geographical term. It is a profound ontological content of the temple, of Jerusalem, the core place of God as home. Zion is the duration of the a-historical.

In Psalm 137: 3 we find the image of Zion in the third verse: "Sing us one of the songs of Zion." At this point, we are able to follow the comparativecontrastive aspect of the historical background of the image of Zion in Psalm $137^{12}$ as contact between the ancient text and the oral poetry of the Macedonian Sephardim:

Thus, Zion was a symbol of refuge and protection, and also a source of joy. However, in Psalm 137 Zion no longer represents refuge and safety, or joy and gladness. Zion has become a source of sorrow. The people remember Zion not

12 For the songs of Zion, see also: Ps. 46, 48, 76, 84, 122. 
with gladness, but with sadness. Because Zion took such a central position in Israel's theology, the fall of Jerusalem and their consequent separation from Zion was an extremely traumatic experience for them. Remembering Zion created grief and a deep inner longing, because the joy of the presence of Yahweh in the temple, and their meeting with him there, now existed only as a memory in their hearts. Zion was destroyed. The security offered by Zion has been shattered. The Zion tradition is turned upside down, thus bringing the experience of bitterness and sorrow so much more into focus. (Maré, 2010, p. 120)

In the ancient text, when the enemy asks: "Sing us one of the songs of Zion," the collective responds with an act of refusal: "How could we sing the LORD's song in a foreign land" (Ps. 137: 4). The foreign land is "a land of abominable deeds" (Ntreh, 2006, pp. 98-99). Exile is "equivalent to descent into the world of the dead; like the dead, the exiles are unable to praise God" (Gillingham, 2012, pp. 91-107). ${ }^{13}$ In the poem Jerusalem of the Sephardim of Monastir, through the covenant we will grow up and we will set you free, God is glorified.

\section{Ethical Sermon Literature in the Process of Enlightenment in Ottoman Macedonia and the Jew as a Chifut}

שמע ישראל יהוה אלהינו יהוה אחד.

[Hear, O, Israel, Adonai is our God, Adonai is one.

Deuteronomy 6:4]

The division between the Greek Patriarchists ${ }^{14}$ and Bulgarian Exarchates, ${ }^{15}$ corresponding to the Ottoman term "Rum", led to the formation of two religious groups and, with that, to the division of Orthodox

\footnotetext{
13 See also: Andor, 2017.

14 After the abolishment of the first Slavic Orthodox Church, the Archbishopric of Ohrid, in 1767, the Greek Church undertook the role of the main loyal partner of the Ecumenical Patriarchate of Constantinople and of the sultan. The understanding of the term "Rum millet" changed: previously denoting all Christians, "Rum millet" became a notion denoting Greeks, even though not all members were Greek. This became more apparent later, with the formation of the Greek state in 1830 .

15 With the sultan's permission, the Bulgarian Exarchate was formed in 1871 (the Bulgarian principality was formed in 1878), and by this act a new religious group was named as well, thus turning the population of the Bulgar millet into a synonym of Bulgarians. Serbia did not have a Serbian Church in the empire, and its activities were conducted over the common Slavic base. After 1815 it acquired semi-autonomous status.
} 
Christianity itself. In this regard, Greek Orthodox and Bulgarian Orthodox (Konortas, 2013, p. 78) represented convertible notions, each of them tending toward becoming a group holding a stable national signifier. While the Greek church nourished the line of the domination of the Greek language among the Slavic population in Ottoman Macedonia, the dominant concept of the Bulgarian Exarchate was applied througha tendency for the supremacy of Christian-Orthodox-Slavic nationalism, taking over education through the Bulgarian language:

Along with the strengthening of nationalism in the 19th century, the Greeks, coming from the higher echelons of the Ecumenical Patriarchate of Constantinople, started to consider the Orthodox institution as a Greek national church. As a result of this understanding, they embarked on a policy of Hellenization among the Orthodox Christians. Normally, such a policy motivated the emergence, firstly of resistance, and secondly of a demand for the establish-ment of one's own national church. In this way, Orthodox Christianity started to lose its universal significance, the process of its fragmentation on a linguistic basis began, and it entered a higher stage of ethnic mobilization. It acquired a Slavic, or, more precisely, South Slavic or anti-Greek dimension. (Donev, 2013, p. 2102)

On the other hand, the Macedonian population suffered through the absence of its theological institution as a political force within the millet system. There was only a weak Macedonian revolutionary movement. These circumstances proved the powerless position of the Macedonian population regarding its self-identification as Macedonian (Donev, 2013, p. 2114). ${ }^{16}$ Against the backdrop of these developments, the political theology of the weak Enlightenment process persisted. It promoted itself through ethical sermon teaching in a language based on the Macedonian native dialect(s) and with that, motivated the earliest Orthodox Slavic national sense among the Macedonian population. Under such complex theopolitical circumstances in Ottoman Macedonia, the Jews simply remained Jews at the center of their theological account, which still secured their only available focus on themselves. They were still constantly confronted with the process of narrowing of the Ottomans' "circle of

\footnotetext{
16 The process of self-recognition was the result of constant conflict between ethnic groups and categories: Greeks, Bulgarians, Serbs, Macedonians. In a continuation in his text, Jovan Donev writes that through the weak process of the Enlightenment, Macedonians persisted on the margins between promotion of the native dialect and Slovenization, which, opposite to the use of the Greek language within the ecclesiastic service, served to expand and support the already imported Bulgarian Slavic Orthodoxy. A large part of the Macedonian population inclined toward the Bulgarian national determination. Later on, the number of Macedonian immigrants in Bulgaria reached 100,000. Many of them believed that the liberation of Macedonia from the Ottomans would occur through the liberation army of Bulgaria.
} 
equality," especially with regard to the seventh principle that "core support of the state is maintained inequality in religion"(Jelavič, 1999, p. 51). This question makes it important to expound the theo-ideological context and also the historical literary use of the term "Chifut", a synonymous notion for identifying the Jew in ethical sermon literature that was part of the Enlightenment process in Ottoman Macedonia.

As a starting point, I will refer to two books, The Mirror (1816, printed in Budim) and Solace of the Sinner (1840, printed in Salonika) by Kiril Pejchinovich (1771-1845), where the noun "Chifut" (çifut) is a pejorative term for a Jew. In its most basic semantic denotation, this term means "a fee." It denotes the Jew as a speculator and greedy materialist, i.e. Chifut is the Jew who cheats for money. This conceptual synonymity of a Chifut and a Jew, and its pejorative, or at least deviant connotation, was no novelty in Pejchinovich's literary language. The placement of the Jew as a rogue trader in the Western European understanding was related to monetary politics involving the fear that the Jews would dominate the European or Christian world:

But while in the Middle Ages they had - with few exceptions - been mere hucksters or usurers, in nineteenth-century Europe the most successful among them became bankers and brokers, financiers and entrepreneurs. Very few, of course, ever reached such heights, but there were enough to provide raw material for new stereotypes. (Lewis, 2005, p. 27)

In opposition to this negative denotation of the Jew, deprived of his spiritual substance, stands the spiritual or divine man within the framework of the Christological conception. According to this, the term "Chifut" does not simply embrace only the negative qualitative attribute of the Jew in a material, monetary or economic sense. It equally includes the theological domain and the theologically and ideologically derived dispute between the two Abrahamic religions. More precisely, the denotation of the Jew, i.e. the Chifut, as material, corporal, carnal, or the one who cheats for money, will remain outside of the spiritual and divine Christological conception, or as Pejchinovich notes in The Mirror, "the New Israel." According to Pejchinovich, the name "new Israel" or "new Jews" was given to the Christians directly from God: "We" have taken the Psalter from the Jews, i.e. from "them," "but we understand" the Psalter (not they) because we have been baptized by the Holy Spirit. "The Jews' hearts turned into stone because they were not baptized and they became mute and deaf. God addressed them so they could hear him and they did not hear him. Thus God has called them Chifuts" (Pejčinovik, 2016, 
p. 26). ${ }^{17}$ And in the Solace of the Sinner, he adds: "they, the Jews, up until the present day are a disgrace among the people and they are called Chifuts" (Pejčinovik, 2016, p. 54).

At the center of this polarization between "we" (the New Israel) and "they" (the Chifuts) there exists an obvious theological conflict. Here, the attempt to insert the theological into the historical level is not the dominant thing, it serves as a reminder: "we are the New Israel, they are Chifuts." This gesture of Kiril Pejchinovich is not at all surprising given that the basic aspiration for building collective consciousness in Ottoman Macedonia followed the route of religious belonging as the most significant criterion for the future national as well as cultural and administrative autonomy. Thus, if the term "Chifut" is a mirror of the Jew, then the religious sermon of Pejchinovich is a mirror of the process of awakening and the establishment of national awareness through the historical perception of an convertible theological term: New Israel, or Christianity. Hence, through the Christological teaching of the New Israel as a collective denominator, Pejchinovich stands out as the earliest motivator among the Macedonian people in their earliest political mobilization around the goal of creating their nation-state. Through canonicalization of life within the framework of ethical sermon teaching and the New Israel, the secular idea for the nation was mobilized. At the same time, the nucleus of Macedonian national consciousness was not experienced as different or separated from Christianity. The nation is a secular name for the Christological New Israel; national unity becomes convertible with Christian unity:

Pejchinovich is recognized as the second representative of the first Enlightenment literary generation. In addition to the Enlightenment movement and printing activities, he also invested strong efforts in support of independence and recognition of the Macedonian Church. (Hristovska-Mironska, 2005, p. 151)

Pejchinovich's activity within this framework was conceived as missionary work, since he was also among the first whose educational activity among the illiterate Macedonian people created the first "cell" (i.e. room) schools. But: "The question is different: What did he [so uneducated] express as a new relation to the Enlightenment in his books, and how?" (Koneski, 1968, p. 50). Pejchinovich, an Orthodox Christian cleric himself, after his church activity at Marko's Monastery near Skopje, left for the Hilandar Monastery on Atos in 1818, to join his father and uncle who were monks there; he later returned to Tetovo, to the village of Leshok, and restored the Monastery of St. Athanasius,

${ }_{17}$ In this paper, I quote from the most recent edition: Pejčinovik, 2016. For comparison, see: Pejčinoviḱk, 1970, 2008. 
where he accomplished and emphasized his historical role as an educator by spreading the Christian religion in a language based on the Tetovo dialect. He also continued the earliest medieval tradition of the Old Slavic teachers from the mid-9th century as well as Damascene literature from the 13th-14th centuries. The printing of his books is considered one of the first examples when books began to enter the homes of the illiterate Macedonians. ${ }^{18}$

In Pejchinovich's work the collective noun "New Israel" denotes the establishment of the Christian community. The grammatical conversion from Old to New Israel explicitly shows two bodies. Here, the political theology gains meaning in the national body created on the basis of a religious or Christological principle. In this way, as Pejchinovich writes following Jesus' words: "This shall be done by you, the sacrifice should be with bread and wine in my memory, to remember me. By doing this, you shall not forget me. You shall remember my dying" (Pejčinovik, 2016, p. 50). Here we can see the doctrinarian translation contained in the term New Israel. It also involves a gesture of the grammatical murder of the original, of the Psalter "which was given to us by them [Jews], but they themselves did not understand it."

In close relation to the grammatical murder of the text stands the doctrine of kurban (deriving from the word karab/karib), meaning "close." Kurban is a sacrifice through which the one who offers it comes closer to God. Namely, the debate about the Chifut's (Abraham's) blood sacrifice and the non-blood, i.e. New Israel's, sacrifice within the liturgical act of communion, is one of the central themes in Pejchinovich's work. On this occasion, again, the dichotomy of the Jew (Chifut) as a material, corporal and carnal being and the man of Christ as a divine or iconic reflection of Christ's values on earth, is emphasized.

Pejchinovich starts the sermon with the words of Isaiah (53:7) placed in the mouth of Christ: "So far you have eaten the bodies of rams and drunk the blood of rams. And this was your honor, your image" (Pejčinovik, 2016, p. 16). In this context, Pejchinovich writes about blood being surpassed by the non-blood sacrifice through which the Holy Spirit breathes, as opposed to the Chifut's blood sacrifice of flesh and blood. Kurban, or the bloody Jewish sacrifice, brings the notion that Chifut is tied to the attribute of gain, money, materialism, attachment to treasure, passion, desire for flesh. The body is alien and superfluous. Such, according to Pejchinovich, is the

18 It is important to note that the second part of the book The Mirror is written in a language based on the Tetovo dialect, with elements from other Macedonian dialects, as well as Old Church Slavic, Serbian and Turkish. For this, see: Hristovska-Mironska, 2007, p. 33; Stalev, 1981, pp. 62-63. 
Chifut's heart (Pejčinovik, 2016, p. 16). In the context of the Jewish sacrifice of flesh and blood, and not of bread and wine, Pejchinovich names the position of the Jews as "dogs in a butcher house" (Pejčinovik, 2016, p. 27). Here the words of St. John Chrysostom (Sveti Jovan Zlatoust, 2008, p. 27) stand as an echo of the Christian sacrifice: "This sacrifice ends not in ashes, is not dispersed in smoke, wants neither wood, nor fire, nor knife. For it has both fire and a knife, even the Holy Spirit."

The non-acceptance of the bloodless sacrifice by the Chifuts makes the Jews unspiritual, and "thus the world hates them, because they are not from this world and they actually live as animals evicted from Heaven, as dogs evicted from a house" (Pejčinovik, 2016, pp. 59-60). The meaning of the phrase "you are not from this world" goes along with the Christian understanding that the Jews could not enter the holiness of Christ's divine kingdom (Kenneth, 1988, p. 73). In this context, it is worth mentioning the line of dual gradation in Pejchinovich's sermon: forward and backward. The gradation forward refers to the fact that by rejecting the liturgical bread and wine, the Jews deprive themselves of life itself, understood as an opportunity to enter the Heavenly Kingdom. The gradation backward in Pejchinovich's work follows the genealogical line or the Jewish ancestral line, of their grandfathers and fathers, and raises the understanding that the Chifuts will die like their ancestors (Pejčinovik, 2016, p. 50). Pejchinovich states: "the Jews were born of lust and thus they are lust. They love lust, not spirituality. They rise in lust, they interpret Christ's advent in lust, not in spirituality. Princes raise your gates... who are these princes that fall? They are the ones that do not open, that do not want to raise the gate and let in the Heavenly King, the King of Glory" (Pejčinovik, 2016, pp. 51-52).

Furthermore, Pejchinovich in his work extends the semantic field of the Chifut over further notions: From the basic semantic meaning of a speculator, a Chifut becomes a wicked person, unbeliever, hooligan and sinner, unrepentant and unforgiven. The Chifut resides in the area of profanity, he is merely flesh and blood, just as the Jewish kurban is flesh and blood (Pejčinovik, 2016, p. 59), without spiritual dimensions that bring the shimmer of enlightenment or metanoia. Pejchinovich preaches that "although the Chifuts have tortured God who came among them, still God is great since he feeds them just as he feeds the Gypsies, the foreign wanderers and the other unbelievers, heretics. God feeds them all in this century, but he does not let them in his kingdom, in his beauty, since they are not worthy" (Pejčinovik, 2016, p. 57).

Besides the Chifuts not wanting to understand that unless they accept the bloodless sacrifice they will die like their ancestors, they also do not understand holy communion. Pejchinovich writes: "the Jews were 
wondering and asked each other, and laughed saying: How can this new law give to us his body to eat and his blood to drink" (Pejčinovik, 2016, p. 49). Again, the identification of the Jews is related to lust. More precisely, the phrase "to eat and to drink" points to a corporal desire of the Jews. They are presented without an ability to understand that it is about spiritual eating of the body (the bread) and spiritual drinking of the blood (the wine); it is about spiritual satisfaction from uniting with the Christians' God. Pejchinovich's literary construction regarding the Jews, who seemingly "mock the fact that they will be eating the body of Christ and will be drinking his blood," is not at all surprising. A part from the fact that we have encountered this previously in his books, it also receives a legitimate or, more precisely, a pragmatic and long-term example in the consciousness of the local Slavic population in Ottoman Macedonia.

Namely, in the time of Pejchinovich's activity, the largest Sephardic community, the Monastirlis, existed in Ottoman Bitola. Blood libel or ritual murder libel was quite a frequent accusation against the Jews made by Christians, i.e. that the Jews murdered and then used the blood of the murdered to prepare the Passover matzah. What is interesting is that accusations of ritual murder in the Ottoman Empire were not only common, but were "typically made in times of economic competitiveness among the Jews and the Christians"(Cohen, 2003, pp. 101-102). This points to hatred felt toward the Jews and their participation in the business climate in Monastir and further afar. This practical and living example of antisemitism in real life was reduced to the parole: "The Jews want our blood" (Cohen, 2003, p. 155). In his Christian ethical sermon work, Pejchinovich accentuates the point that the Jews laughingly wonder "what it would be like to eat the body of Christ and how they will drink his blood." All this gains univocality not by analogy, but by genealogy, a cause-andeffect and linear sequentiality in the expressed qualitative determination of the Jew as a liar, as someone who drinks blood, who tortured the body of the last blood sacrifice (Jesus). The Jew stays external since he is corporal, he is a body without spirit and soul, lustful, filled with passions and a desire for material gain, someone who is not close to God in the strictest and most precise meaning of the word - with the Christian God. His heart remains a Chifut's heart, and he, the Jew, remains a Chifut, an outsider in the grammatical, theopolitical and sociocultural contextual understanding of ethical sermon literature in the process of the Enlightenment and the earliest national mobilization in Ottoman Macedonia. 


\section{Concluding Remarks}

The highest level of migration among the Monastirlis was recorded during the last decade of the Ottoman Empire's existence. In the period between 1900-1912, when Macedonia was still one of the last possessions of the Ottoman Empire, hundreds of Monastirlis migrated to America. ${ }^{19}$ Following the Young Turk Revolution of 1908 (when the empire became a parliamentary monarchy), led by a group of Western European and reform-minded officers and intellectuals, the constitutional government of the Young Turks introduced a decree restricting the exercise of political power to political groups. The equality of all faiths, and the equal right to linguistic and cultural diversity of religious minorities, became unsustainable.

To conclude, I would like to return to the actual starting point of the present paper, to the very literary beginning, to "Jerusalem, Jerusalem, our mother/We shall grow up/We shall grow up." It is obvious that the theomessianic desire for the home is possible and accomplishable only in history and probably only in that very moment "when the non-theological disrupts, the theological history interrupts" (Raz-Krakotzin, 2007, pp. 530-543). However, speaking of secularism, it is worth mentioning that Europe restlessly and on several more occasions overstepped the threshold of new and even more dangerous wars after the fall of the Ottoman Empire, all in the name of secularism as a political doctrine which has never actually broken its ties with the theological. To be more precise, with the kind of theological that best suits Europe's aims, but also the one on whose basis Europe legitimizes itself: Christianity.

\section{References}

Albvaš, M. (2015). Kolektivno i istorijsko pamćenje. In M. Sladeček, J. Vasiljević, \& T. Petrović Trifunović (Eds.), Kolektivno sećanje i politike pamćenja (pp. 29-60). Institut za filozofiju i društvenu teoriju.

Alkalaj, D. (1910). O Cionizmu: Njegov značaj i razvitak. Društvo Cion.

Andor, B. J. (2017). Psalm 137: Israel's remembrance of Zion in exile. International

19 The second migratory wave occurred during the two Balkan Wars when 30\% of Monastir Jews left Macedonia for America. According to the Treaty of Bucharest, concluded on August 10,1913, Macedonia was divided amongst Greece (Aegean Macedonia), Serbia (Vardar Macedonia), Bulgaria (Pirin Macedonia) and Albania (western part of Macedonia). The third migratory wave to America took place during World War I, when Macedonia was divided amongst Serbia, Bulgaria and Greece. 
Journal of Innovative Studies in Sociology and Humanities, 2 (1), 2456-4931.

Asman, A. (2015). Sećanje, individualno i kolektivno. In M. Sladeček, J. Vasiljević, \& T. Petrović Trifunović (Eds.), Kolektivno sećanje i politike pamćenja (pp. 71-86). Institut za filozofsku i društvenu teoriju.

Asman, J. (2011). Kultura pamćenja. Prosveta.

Benbasa, E., \& Rodrig, A. (2011). Istorija na sefardskite Evrei od Toledo do Solun. Slovo.

Cohen, M. (2003). Last century of a Sephardic community, The Jews of Monastir, 18391943. Foundation of Sephardic Studies and Culture.

Donev, J. (2013). Makedonija (1850-1913). In P. Kuzman, J. Donev, \& E. Dimitrova (Eds.), Makedonija: Mileniumski kulturni i istoriski fakti (Vol. 4, pp. 2095-2182). Forumplus.

Foucault, M. (1984, October). Of other spaces: Utopias and heterotopias (J. Miskowiec, Trans.). Architecture Mouvement Continuité. https://web.mit.edu/allanmc/ www/foucault1.pdf

Gillingham, S. (2012). Seeing and hearing Psalm 137. In K. Eyjar (Ed.), Mótun Menningar / Shaping Culture. Afmoelisrit / Festschrift Gunnlaugur Jónsson (pp. 91-107). HidÍslenska Bókmenntafélag.

Ǵorgiev, D. (2008). Makedonija pod osmanliska vlast (od krajot na 14-do krajot na 18 vek). In T. Čepreganov (Ed.), Istorija na makedonskiot narod (pp. 125-163). INI.

Ǵorgiev, D. (2013). Makedonija vo osmanliskiot period (istorija). In P. Kuzman, J. Donev, \& E. Dimitrova (Eds.), Makedonija: Mileniumski kulturni i istoriski fakti (Vol. 4, pp. 1869-1956). Forumplus.

Grandakovska, S. (Ed.). (2011). The Jews from Macedonia and Holocaust: History, theory, culture. Euro Balkan Press.

Hristovska-Mironska, V. (2005). Prosvetitelstvoto vo Makedonija. IML.

Hristovska-Mironska, V. (2007). Makedonskata prerodba. IML.

Jelavič, B. (1999). Istorija na Balkanot: Osumnaesetti i devetnaesetti vek (Vol. 1). List.

Katz, S. (Ed.). (2012). The Torah commentary of Rabbi Shlomo Carlebach: Genesis (Pt. 1). Urim Publications.

Kenneth, R. S. (1988). Hatred of the Jews or love of the Church: Papal policy toward the Jews in the Middle Ages. In S. Almog (Ed.), Antisemitism through the ages (pp. 91-111). Pergamon Press.

Kolonomos, Ž. (Ed.). (1978). Poslovice, izreke i price sefardskih Jevreja Makedonije. Savez jevrejskih opština Jugoslavije.

Koneski, B. (1968). Kiril Pejčinovik, predgovor. In K. Pejčinoviḱ, Slovo za praznicite (od Ogledalo) (pp. 9-55). Kultura.

Konortas, P. (2013). Nationalist infiltrations in Ottoman Thrace (ca. 1870-1912) in the case of the Kaza Gumuljina. In B. C. Fortna, S. Katsikas, D. Kamouzis, \& P. Konortas (Eds.), State-nationalisms in the Ottoman Empire, Greece and Turkey, Orthodox and Muslims (1830-1945) (pp. 73-100). Routledge-Taylor \& Francis Group. 
Lewis, B. (2005). Anti-Semites. In S. Gigliotti \& B. Lang (Eds.), The Holocaust: A reader (pp. 17-43). Blackwell Publishing.

Luria, A. M. (1930). A study of the Monastir dialect of Judeo-Spanish based on oral material collected in Monastir, Yugoslavia. [n. p.].

Maré, L. P. (2010). Psalm 137: Exile - not the time for singing the Lord's Song. Old Testament Essays, 23(1), 116-128.

Mueller, E. (2008). A History of Jewish Mysticism. Mysticism in the Bible, Chassidic Mystics, the Talmud, the Zohar, Kabbalah. Sefer VeSefel Publishing.

Ntreh, A. B. (2006). A concise history of ancient Israel and Juda. Marcel Hughes.

Pejčinovik, K. (1970). Izbrani tekstovi. Makedonska kniga.

Pejčinovik, K. (2008). Stihovi na glas trapezečki (nadgroben natpis), 1835. In G. Todorovski (Ed.), Književnata prerodba (p. 3). NID Mikena.

Pejčinovik, K. (2016). Pouka za sekoj hristijanin, izvadok od Ogledalo, prisposobuvanje na sovremen makedonski jazik, pojasnuvanja i komentari arhimandrit Irinej (Stefanovski). N. Stefanovski.

Raz-Krakotzin, A. (2007). Jewish memory between exile and history. The Jewish Quarterly Review, 97 (4), 530-543. https://doi.org/10.1353/jqr.2007.0061

Sadikario, A. (2008). Koreni. Evrejska zaednica vo RM.

Sládeček, M., \& Vasiljević, J. (2015). Problematičnost pojma "kolektivno sećanje". In M. Sladeček, J. Vasiljević, \& T. Petrović Trifunović (Eds.), Kolektivno sećanje i politike pamćenja (pp. 7-59). Institut za filozofsku i društvenu teoriju.

Sodža, E. (2007). Istorija, geografija, modernost. In I. Džeparoski (Ed.), Aspekti na drugosta: Zbornik po kulturologija (pp. 45-62). Evro Balkan Press.

Stalev, G. (1981). Istorija na makedonskata književnost: Makedonskata literatura vo 19 vek (Vol. 1). IML.

Sveti Jovan Zlatoust. (2008). Zošto ne biva da mu posakuvame zlo na drugiot: Besedi za borba so strastite. Pravoslaven Pat.

Vidaković-Petrov, K. (2009). Usmena poezija španskih Jevreja (Sefarda) i balkansko kulturno okruženje. Književna istorija, 41(137/138), 395-408.

Vidaković-Petrov, K. (2011). Corpus of Sephardic folklore from Macedonia. In S. Grandakovska (Ed.), The Jews from Macedonia and Holocaust: History, theory, culture (pp. 538-559). Evro Balkan Press.

\section{Мнемотопот Сион и теополитичките хронотопи во отоманска Македонија}

Дискусијата во овој труд, преку книжевна и историска дисциплинарна интерсекција, оралната поезија и етичките проповеди од периодот на просветителското движење во отоманска Македонија, цели кон афирмирање на споредбената врска меѓу две прашања. Првото 
прашање е: Како да се достигне Сион (разбран како мнемотоп) во отсуство на политички идентитет на Сефардите од Монастир (Битола) во рамки на отоманскиот милет-систем? Второто прашање во трудот е: Како тео-месијанскиот копнеж по Сион (сфатен како вертикална историја) е остварлив и дистиглив во линеарноста на историајта, во контекст на постоечките политички хронотопи или тн. Ортодоксни национализми во отоманска Македонија? Во рамки на овој сложен период, отуствува реалното политичко место нас ликата за Сион, но таа се пак останува да ослободува важна смисла за татковината како духовен простор.

Клучни зборови: сликата за Сион, Монастирлии, отоманска Македонија, ортодоксни национализми, просветителство, мнемотоп, семантика на меморија, хронотоп.

\section{Mnemotyp Syjonu i teopolityczne chronotopy w osmańskiej Macedonii}

Zaprezentowana $\mathrm{w}$ niniejszej pracy dyskusja ma na celu potwierdzenie związków pokrewieństwa między dwoma pytaniami: jak dotrzeć do Syjonu (rozumianego jako mnemotyp) przy braku politycznej tożsamości Sefardyjczyków z Monastyru/ Bitoli, w ramach systemu osmańskiego milletu? Drugie pytanie postawione w tekście brzmi: w jaki sposób teomesjanistyczne pragnienie Syjonu (rozumiane jako historia wertykalna) jest możliwe i osiągalne w historii linearnej, w kontekście istniejących politycznych chronotypów lub tak zwanych chrześcijańsko-prawosławnych nacjonalizmów w Macedonii osmańskiej?

W artykule posługuję się analizą komparatystyczną w kluczu interdyscyplinarnym, który stwarza podstawy do połączenia literatury i historii, poezji ustnej i etycznych kazań z okresu oświecenia w Macedonii osmańskiej.

Słowa kluczowe: obraz Syjonu, Monastirlis, osmańska Macedonia, nacjonalizmy chrześcijańsko-prawosławne, oświecenie, mnemotyp, pamięć semantyczna, chronotop.

Przekład z języka macedońskiego Jolanta Sujecka 


\section{Note}

Sofija Grandakovska, John Jay College of Criminal Justice, City University of New York, New York.

grandakovska@gmail.com, sgrandakovska@jjay.cuny.edu

The preparation of this article was self-funded by the author.

No competing interests have been declared.

\section{Publication History}

Received: 2020-05-24; Accepted: 2020-12-04; Published: 2020-12-31 